Neslihan Derin
İnönü University, neslihan.derin@inonu.edu.tr, Malatya-Turkey

http://dx.doi.org/10.12739/NWSA.2017.12.2.3C0160

YÖNETICIILERIN, ENTELEKTÜEL LIDERLIKK DÜZEYLERININ ÖRGÜTSEL YARATICILIĞA KATKISI: MALATYA ÖZEL HIZMET İŞLETMELERINDE BİR ARAŞTIRMA

Öz

Hizmet işletmeleri, yoğun rekabetin ve değişimin olduğu iş hayatında etkinliklerine devam etmektedirler. Günümüzün bilgi toplumunda özellikle hizmet işletmeleri, düşünme yeteneği gelişmiş, bilgili, becerikli ve genel kültürü iyi, yüksek eğitimli, entelektüel liderlere ihtiyaç duymaktadırlar. Bu liderler, çalışanların yenilikçi, yaratıcı kabiliyetlerinin geliştirilmesinde ve bir bütün olarak işletmeye bu özelliklerin katılmasında anahtar unsurlar olarak düşünülmektedir. Daha önceki araştırmalarda örgütsel yaratıcılığa etki eden diğer liderlik türleri ele alınmışken, örgütsel yaratıcılık üzerinde en önemli etkiyi oluşturacağı düşünülen entelektüel liderliğin Türkçe yazında işlenmediği görülmüştür. Bu araştırmanın sorunsalı; entelektüel liderlik örgütsel yaratıcılığı ne oranda açıklamaktadır? Araştırmanın temel amacı ise entelektüel liderliğin, örgütsel yaratıcılık üzerindeki etkisini ortaya çıkarmaktır. Araştırma sorusuna cevap verebilmek için korelasyon, çoklu regresyon testleri yapılmıştır. Analizler için SPSS 21.0 programından yararlanılmıştır. Malatya merkezde çeşitıi özel hizmet işletmelerinde (eğitim, finans, sağlık) çalışan 283 kişinin katıldığı araştırma sonuçlarıyla entelektüel liderliğin örgütsel yaratıcılık üzerinde belirleyici bir etkiye sahip olduğu ortaya konmuştur.

Anahtar Kelimeler: Entelektüel, Entelektüel Liderlik, Örgütsel Yaratıcılık, Bilgi Toplumu, Hizmet İşletmeleri

\title{
CONTRIBUTION TO ORGANIZATIONAL CREATIVITY OF LEVEL INTELLECTUAL LEADERSHIP OF THE EXECUTIVES: A RESEARCH IN MALATYA SPECIAL SERVICES BUSINESS
}

\section{ABSTRACT}

Service businesses are continuing their activities in work life where intense competition and change are occurring. In today's information society, especially services business need intellectual leaders who have improved their thinking skills, are knowledgeable, skillful, with high education. It is believed that intellectual leader is key element to develop innovation, creativity of workers and to help these workers contribute these features to the business. While other types of leadership that influence organizational creativity has been investigated, intellectual leadership that influences organizational creativity most hasn't been investigated in Turkish literature. This research aims to find out How far intellectual leadership explains organizational creativity. The study also aims to find out the impact on organizational creativity of intellectual leadership. In an attempt to answer the research questions, correlation, multiple regression tests were employed. SPSS 21.0 software was also utilized for the research analyses. The research was conducted with the participation of 283 workers from private service businesses (education, finance, health) in the city center of Malatya province. This study concludes that intellectual leadership has a determining impact on organizational creativity.

Keywords: Intellectual, Intellectual Leadership, Organizational Creativity, Information Society Service Businesses

How To Cite:

Derin, N., (2017). Yöneticilerin, Entelektüel Liderlik Düzeylerinin Örgütsel Yaratıcılığa Katkısı: Malatya Özel Hizmet İsletmelerinde Bir Arastırma, Social Sciences (NWSASOS), 12(2):102-117, DOI: 10.12739/NWSA.2017.12.2.3C0160. 


\section{GIRISS (INTRODUCTION)}

20.yy ikinci yarısında, bilim ve teknolojideki hızlı gelişmeler bilgi çağını meydana getirmiştir. Bilgi çağı esnasında, ülkelerin ekonomik ilerlemeleri, bilgiyi üretme kapasiteleriyle yakından ilişkili hale gelmiştir (Uslu, 2016:193). Bu gelişmeler, çeşitli sektörlerde bilgi iş̧̧iliğinin önemini artırmış ve sektörel ağırlığın sanayiden hizmet sektörüne doğru kaymasına yol açmıştır (Tekin, 2005:521). Hizmet işletmeleri, yoğun rekabetin ve değişimin görüldüğü iş hayatında etkinliklerine devam etmektedirler. Böyle bir değişim ve hareketlilik ortamında örgüt modelleri değişik açılardan yeniden tasarlanmakta, yeni ürün ve yaratıcılık süreçlerinden faydalanılarak ürünlerin marka payları artırılmaya çalışılmaktadır. Böyle bir ortamda işletmeler için gerekli olan paradigma değişimlerinden birisi de liderlik alanında olmaktadır (Ünal, 2011). Liderin günümüzdeki rolü, kontrol etme veya emir vermekten daha çok örgüt içindeki yaratıcılığı ve enerjiyi ortaya çıkarmaktır (Dealtry, 2001:121). Örgüt içerisinde yaratıcı bireyler ancak örgütsel boyutta yaratıcılığın desteklendiği bir ortamda var olabilirler. Örgütlerin iş ortamında yaratıcılığı ve yeniliği geliştirebilmesinde anahtar katalizör görev, yeterli sayıda yetişmiş ve motive olmuş liderlere düşmektedir. Sıra dışı, geleneksel olmayan lider davranışları, örgütlerde yaratıcılığı geliştirme ve etkinleştirmede önemli rol üstlenir. Bu davranışları sergileyen liderler, çalışanları için "rol model" olurlar.

Liderler, çalışanları, kendileri gibi farklı ve yaratıcı düşünmeye özendirerek, örgütlerin faydalarını ve kazançlarını birçok çıkar gurubu açısından artırabilirler (Cengiz, vd, 2007:104). Bu ifadelerden yola çıkarak iş ortamında yaratıcılığın ortaya çıkması için en önemli unsurlardan birisinin liderlik olduğu söylenebilinir (Tierney, vd, 1999:592). Nitekim daha önce yapılan araştırmalarla yaratıcılığın, lider üye arasındaki etkileşimle (Chughtai, 2016) liderin duygusal zekasıyla, (Zhou-George, 2003; Aktaran: Cengiz, vd, 2007:199), liderin, çalışanların his ve duygularını anlamaya dönük davranışlarıyla, etik liderlik (Uğurlu ve Ceylan, 2014; Chughtai, 2016) vizyoner liderlik (Yllmaz ve Karahan, 1010), transformasyonel liderlik (Qu, vd., 2015) gibi liderlik tarzlarıyla ilişkili olduğu ortaya konmuştur (Yılmaz ve Karahan, 2010:156). Özellikle düşünme yeteneği gelişmiş, bilgili, becerikli, genel kültürü iyi ve yüksek eğitimli entelektüel liderlerin (Demir Uslu, 2011:431) örgütsel yaratıcılığa nasıl katkı sağladığı ise merak konusudur. Bu çalışmayla, bu merak konusunun giderilmesine katkı sağlanacağı düşünülmektedir. Yukarda verilen bilgiler doğrultusunda bu araştırmanın amacı: "özel hizmet işletmelerinde entelektüel liderliğin, örgütsel yaratıcılık üzerinde ne derece etkili olduğunu ortaya koyabilmek" olarak tasarlanmıştır. Bu doğrultuda Malatya ilinde faaliyet gösteren çeşitli sektörlerdeki (eğitim, finans, sağlık) özel hizmet işletmelerinden anket yöntemiyle veriler toplanmış ve analiz edilmiştir.

\section{2. ÇALIŞMANIN ÖNEMI (RESEARCH SIGNIFICANCE)}

Entelektüeller, bilgi birikimleri, donanımlarıyla topluma yön veren kişilerdir. Hizmet işletmeleri yöneticilerinin entelektüel liderlik düzeyleri, örgütlerinin çă̆ın gerektirdiği donanımları kazanmalarında anahtar unsur olarak görülmektedir. İşletmelerin rekabet üstünlüğü elde edebilmeleri ve sürdürebilmeleri, yenilikçi ve yaratıcı olma kabiliyetleriyle yakından ilgilidir. Bu kabiliyetlerin varlığı ve gelişmesi yöneticinin entelektüel liderlik seviyesiyle yakından ilişkili olduğu düşünülmektedir Yazında örgütsel yaratıcılık ile diğer bazı liderlik türleri arasındaki ilişkiler ve bu liderlik 
Derin, $N$.

Social Sciences (NWSASOS), 3C0160, 2017; 12(2): 102-117.

türlerinin örgütsel yaratıcılık üzerindeki etkileri araştırılmasına rağmen entelektüel liderliğin örgütün yaratıcılık kabiliyetini ne derece aktive ettiği yeterince tartışılmamıştır.

\section{LITERATUR INCELEMESI (LITERATURE REVIEW)}

\subsection{Entelektüel Liderlik (Intellectual Leadership)}

Entelektüel, etimolojik olarak Latince "intellectus" tan türemiş; Intellectual'in kökü ise intelec'tir. Intellect, beyin, zihin, akıl, kudret, idrak ve uyanıklık anlamına gelir (Çağan, 2005a:11). Geçmiş çă̆lardan beri, bilgi üreten, çeşitli düşünme yolları geliştiren, eğitimli, toplumu yönlendiren kişiler entelektüel olarak kabul edilmektedir (Uslu ve Arslan, 2015:127). Bu doğrultuda entelektüel, geleneksel anlamı içinde, düşünsel veya zihinsel etkinliği kendine faaliyet alanı olarak seçmiş, bilgili, değerlendirme ve eleştiri gücü yüksek, topluma yol gösterici olma misyonu yüklenmiş, aydın, çă̆daş kişi olarak tanımlanabilmektedir (Yılmaz, 2007:4). Günümüzde yazar, gazeteci, edebiyatçı, tarihçi, bilim adamları, gibi daha çok kamusal ve toplumsal konulara ilgi duyanlar "entelektüeller" olarak kabul edilir. Entelektüel derinliği ve yetkinliğiyle, kurumu dönüştüren, geliştiren rekabetçi kılan, devlet, özel sektör yöneticileri de günümüz entelektüelleri arasında sayılabilir (Akdemir, 2008:127). Bu kimseler, entelektüel başarılarından dolayı sosyal açıdan ayrıcalıklı kişilerdir (Macfarlane ve Chan, 2014:296). Toplumun bir üyesi olarak karmaşık bir toplumsal role sahip entelektüellerin temel vasıfları, bireysel ve toplumsal vicdanın teyakkuz hali olmak ve içinde bulundukları topluma dünyanın yorumunu sunmaktır (Çağan, 2005b:157). Entelektüeller; eskimiş olana muhalefet ve dönüştürücü liderliğe katkıda bulunarak geçmişle geleceği buluşturur. Bilginin belirlediği bir geleceği, geçmişin modern duruşunu biçimlendirmek suretiyle, bugünden tasarlayan entelektüel, diğer yandan da temsil ettiği gruplar adına hemen her alanda, akli çözümler ve politikalar üretmekten de geri durmaz. Bütün bu faaliyetlerin gerçekleştirmesinde, entelektüelin sahip olduğu en önemli gücü; bilgi, beceri ve deneyimlerin bileşimini temsil eden entelektüel sermayesi olacaktır (Koç, 2006:167).

Entelektüeller, zekâ, yargı gücü, merak, yaratıcılık, güzelliğe duyulan beğeni, düşünce ve kuşkuyla beslenen eleştiri gibi yetenekleriyle öne çıkarlar (Çağan, 2005b:157). Entelektüel liderlik kavramı; liderliğe yeni bir kimlik kazandırmak, farklı bir bakış açısı veya yaklaşım getirmek üzere tasarlanmış olmakla birlikte, liderlik ve entelektüellik kavramlarının eş değer bileşimini ifade etmektedir (Koç, 2006:203). Bryman (1992) lideri bir grubun üyelerini belirli bir hedef doğrultusunda, bir sosyal etki süreci aracılığı ile yönlendiren kişi olarak tanımlamıştır (Aktaran: Ayyıldız Ünnü, 2014:36). Lider, grubun açığa çıkarılmamış ancak ulaşmak istedikleri sonuçları belirledikten sonra onları etkileyerek davranışa yöneltmektedir (Mısırdalı Yangil, 2016:130). Lider, yönlendirme, harekete geçirme, tahsis etme, geliştirme gibi temel işlevleri yerine getirirken; bilgelik, zekilik ve yaratıcılık gibi üç temel yetkinliğe sahip olmak zorundadır. Bu üç anahtar unsur, bir lider olarak doğulmaya gerek bırakmadan aslında her birey tarafından geliştirilebilecek yetkinlikler olarak görülmelidir. Aynı zamanda bir entelektüele de ithaf edilebilecek bu anahtar faktörler, özellikle bugünün liderleri için yaşamsal nitelikteki yetkinliklerdir (Koç, 2006:203). Entelektüel liderliğin gelişimi bilgi toplumunun gelişimi ile eş zamanlı olarak gerçekleşmiştir. Yeni ekonomik süreçlerin, hızlı bir şekilde, toplumu ve örgütleri, bilgiyi oluşturan ve içselleştiren konuma getirmesiyle, entelektüel liderlik popüler liderlik modeli haline gelmiştir 
(Söylemezoğlu, 2011). Bilgi toplumunda mal üretimi yerine, bilgi üretimi ve yönetimi öne çıkmaktadır. Bu durum, yenilik, farklılık ve yaratıcılığı örgütler için zorunlu yetkinlikler haline getirmektedir. Yeniliği, farklılığı ve yaratıcılığı yönetmek, entelektüel birikimi gerekli kılmaktadır (Akdemir, 2008:132). Entelektüel lider hem moral hem de fonksiyonel açıdan grubun üstünde olan kişidir (Macfarlane, 2011:71). Entelektüel liderler, yönetim kavramı ve süreçleri konularında analitik düşünebilen, bilgiyi etkin kullanan, değer yaratmaya odaklı, paylaşılan sorumluluk ve tersine yönetim anlayışını benimsemiş, takım üyelerine, kendilerini motive edebilecekleri bir ortam oluşturarak üyelerin kendi kendilerini yönetme yetkinliğiyle donatan liderlerdir (Yılmaz, 2004). Kısacası entelektüel lider, örgütün dinamikliğini gösteren önemli bir belirteçtir (Dealtry, 2001:121).

Güç, insanların, başkalarının davranışını istedikleri biçimde değiştirmelerine imkân verir (Yılmaz, 2007:176). Entelektüel Liderin; formal, karakter ve bilgi gücü olmak üzere üç temel güç kaynağı vardır (Akdemir, 2004). Entelektüel lider gücünü daha çok bilgisinden alır. Geçmişte "bilgi güçtür" ifadesi bireyi ön plana çıkarmaktaydı. Bilgi paylaşımını sağlayan bir örgütte bu ifade artık bireysel değil, örgütsel bir boyut kazanmaktadır (Yılmaz, 2014:51-52). Bilginin önemi, açık bir sistem olan örgütlerin, iç ve dış çevrelerinden elde ettikleri enformasyonu, kendi iç işleyişlerinde, rekabet, yenilik, yaratıcılık ve verimlilik temelinde kullanmalarından kaynaklanmaktadır (Yılmaz, 2014:57). Giderek liderler, bilginin paylaşılmasında daha cömert davranmak zorunda kalmaktadırlar çünkü bilgiye hükmetme yeteneği veya yeterliliği oranında, kendi yetkinliğini tescil etme gücünü elinde bulundururlar (Çağan, 2005a:21). Bütün bunlardan sonra hem entelektüel ve hem de lider olmasıyla "Bilgi Toplumu Lideri" olarak tanımlanan "Entelektüel Liderin", çalışanların gereksinimlerinin yön ve şiddetini en iyi anlayacak, kestirecek ve buna uygun motivasyon araçlarını saptayacak kişi olacağını söylemek yanlış olmayacaktır (Koç, 197:2006). Bilgi çağında rekabet üstünlüğü elde edebilmeleri için örgütler, tüm çalışanlarının bilgi, yetenek, tecrübe, yargı ve en önemlisi de yaratıcılıklarına ihtiyaç duymaktadırlar (Dess, Picken, 2000:18). Örgüt içinde keşfedilmemiş çalışan yeteneklerine ulaşılması, çalışanların yenilik yapabilme, yaratıcı faaliyetlerde bulunabilmelerini sağlayan bir örgütsel ortamla mümkün olabilir.

\section{2. Örgütsel Yaratıcılık (Organizational Creativity)}

F.Taylor'a göre yaratıcılık; "yeni ve geçerli fikirler yaratılmasıyla sonuçlanan fikirsel süreçtir" (Budak ve Budak, 2004:591). Rouqette'e (1992) göre ise yaratıcılık; kişi, işlem ve ürünün birbirleriyle kaynaşmasından oluşmaktadır (Erdoğdu, 2006:95). Yaratıcılık ve örgütsel yaratıcılık birbiriyle ilişkili kavramlardır. Örgütsel yaratıcılık, kişilerin tek tek veya gruplar halinde örgütün yararına olacak, yeni fikir, süreç ve ürün geliştirebilme kabiliyetlerinin toplamıdır (Yılmaz, 2010:3950). Bir başka ifadeyle örgütsel yaratıcılık, yeni ve faydalı fikirlerin, örgüt içerisinde prosedürlere, süreçlere, ürünlere ve hizmetlere dönüştürülmesidir (Cheung ve Wong, 2010:656). Örgütsel yaratıcılık, beraber çalışan bireyler tarafından oluşturulan değerli, yararlı, yeni bir hizmet, fikir veya süreçtir (Uğurlu, Ceylan, 2014:98). Yaratıcılık, önce bireysel olarak başlar sonra örgütün çalışanlarına uygun ortamlar hazırlaması ve onları bu doğrultuda desteklemesiyle örgütsel yaratıcılığa dönüşür (Yıldırım, 2007:109). Örgütsel yaratıcılığın entelektüel ve pratik olmak üzere iki boyutu vardır. Entelektüel 
boyutu, yenilikler üzerinde düşünmeyi, fikirler oluşturmayı içerirken, pratik boyutu ise yeni fikirlerin işleme geçirilmesi, ete kemiğe büründürülmesi aşamasını ifade etmektedir (Mainemelis ve Ronson, 2006:93). Günümüzün yoğun rekabet ortamında yaratıcılık, işletmenin rekabet avantajı elde etmesinde ve başarılı olmasında anahtar unsurdur (Dewett ve Gruys, 2007:85; Cheung ve Wong, 2010:656; Gümüşlüoğlu ve Ilsev, 2009:462). Yaratıcılık, örgütlerin yenilikçi potansiyelinin temelini oluşturduğundan, varlıklarını davam ettirebilmelerinin öncülüdür (Kratzer, vd, 2008:269). Yaratıcı iş takımlarında yer alanların, düşünsel yeteneklerinin uygulamaya geçmesiyle, inanılmaz deneyimler yaşayarak işin önemli bir kısmını kendilerinin yaptığı hissiyle, içsel motivasyonları oldukça yükselir (Matthews, 2008:75-95; Yurtseven, 2001:27). Bu tür çalışanların, zihinsel algıları açık ve iç enerjileri yüksektir (Phillips, 2007:163). Bu enerji, çalışanların verimini, dolayısıyla da işletmenin verimini (Serhat, 2010:2280), rekabet avantajı elde etme (Akdemir, 2008:224) ve dış çevreye adapte olabilme yeteneğini yükseltebilmektedir. Örgütsel yaratıcılığın, ancak uygun ortamda ve uygun bir çevrede gelişebileceği, yapılan araştırmalarla ortaya konmuştur (Uysal, 2007:143).

Araştırmaların ortaya koyduğu gibi, örgütsel yaratıcılığın ilerletilmesinde veya geriye gitmesinde diğer örgütsel faktörler önemli etkilere sahiptirler (Rice, 2006:233). Bu faktörlerden biriside liderliktir. Bireysel yaratıcılık, kişiler tarafından içselleştirilerek, örgüt içinde yayılarak, örgütsel yaratıcılığa dönüştürülmedikçe, örgütsel sermayeye eklenememektedir. Bireysel yaratıcılığın, örgütsel yaratıcılığa dönüşme sürecinde en büyük görev yönetime, lider yöneticilere düşmektedir. Liderin, sorunları ve sorunlara yönelik çözüm önerilerini, yeni düşünce ve fikirleri değişik yönlerden ele alması, konulara daha geniş açılar getirmesi gerekir. Lider, takım çalışmasını teşvik etmek suretiyle, bireysel yaratıcılıkları, takım yeteneklerine dönüştürmek, ardından örgütsel yaratıcılığı sağlayarak, yaratıcılığı bir örgüt dinamiği haline getirmekle yükümlüdür (Yıldırım, 2007:110). Örgütsel Yaratıcılık için tüm yapılması gerekenleri yapabilecek kapasitede olan ve örgütsel kapasitenin artışında etkin rol alabilecek kişi entelektüel liderdir. Entelektüel lider, değiştirme, dönüştürme ya da katılımla yetinmemekte, çalışanların, örgüte değer katan fikir ve yaratıcı yaklaşımlarına her zaman olumlu bakan bir düşünce içerisindedir. Bu durum, örgütü sadece fikir şampiyonu yapmakla bırakmayacak, beraberinde işbirliğini teşvik eden, haz duyulan bir çalışma ortamı ve kültürü de biçimlendirecektir (Ünal, 2011).

\subsection{Entelektüel Liderlik ve Örgütsel Yaratıcılık (Intellectual Leadership and Organizational Creativity}

$\mathrm{Bu}$ iki olgu arasındaki ilişkiyi açıklamak için Fred Fiedler'in etkin liderlik kuramından faydalanılmıştır. Bu kuramın temelinde, grup performansının, liderlik tarzı ve ortam özelliklerinin bir fonksiyonu olduğu düşüncesi yatmaktadır (Tabak ve Sığrı, 2014:396). Toplumu birleştirecek düşler kurabilme, herkesin harcı değildir. Bütün bunları ancak entelektüel yapabilir. Eleştirel düsünme yapısına sahip entelektüel bireyler topluma çeşitli projeler sunar; onları uygulamanın önemli olduğunu söyler; kendine güvenenleri harekete geçirebilir ve böylece büyük işler başarabilir (Yılmaz, 2007:3; Özsevgeç ve Aytar, 2014:642). Entelektüel, her şeyden önce yaratıcı bir düşün insanıdır (Akdemir, 2002). Simonton, en ünlü yaratıcı kişileri ve liderleri dikkatle incelemiş, yaratıcılığın başlı başına bir liderlik türü olduğunu ve yaratıcılık ile liderlik arasında var olan ayrımın ortadan kalktığını ileri sürmüştür. Norris, liderliğin, 
Derin, $N$.

Social Sciences (NWSASOS), 3C0160, 2017; 12(2): 102-117.

\begin{abstract}
değişimin yeni yollarını kavramsallaştırabilen, problemleri tanımlayabilen, olması gereken şeyin ışığında, şimdiki durumları analiz etme yeteneğine sahip olan bir lider kapsamında, yaratıcılık gerektirdiğini kabul etmektedir (Goertz, 2000:158; Akt: Yılmaz, 2007:183). Lider zekası ve irade gücüyle, elindeki imkanlar ölçüsünde, astlarını örgüt amaçlarına ulaşmak için yönlendiren kişidir (Tabbasi vd, 2016:340). Lider ve motive ettiği çalışanların birlikte amaçlara ulaşma konusunda gösterdikleri çabanın düzeyi ve ortaya konulan performans, liderin sergilediği tutum ve bakış açısıyla ilgilidir (Yılmaz, 2014:54). Entelektüel liderin yaratıcılık yönünde sergileyeceği tutum ve davranışlar, tüm çalışanları etkileyebilir. Entelektüel liderler, diğer liderlerin çok üstünde bir düzey ve performansla yaratıcılık özelliğine sahip olduğu gibi entelektüel liderlik de; örgütlerin kendi yeteneklerinin farkına vararak, dinamik ve rekabete duyarlı prosesler oluşturmasında, çalışanlara kendini kanıtlama firsatı sunularak, yaratıcılık performanslarının artırılmasında dolayısıyla yüksek katma değer elde edilmesinde etkili bir liderlik modelidir (Yllmaz, 2004). Bu liderlik modeli, yüksek düzeydeki yaratıcı performans ile sürekli yeniyi araştıran, eskiyi ve mevcut olanı eleştirerek sorgulayan bir liderlik yapılması anlamına gelmektedir. Entelektüel liderin oluşturacağı, sınırsız yaratıcılık süreci Tablo 1'de ortaya konulmaya çalışılmıştır.
\end{abstract}

Tablo 1. Entelektüel liderliğin zamanla örgütsel yaratıcılığı etkilemesi

(Table 1.Influence of intellectual leadership on organizational creativity at over time)

\begin{tabular}{|c|c|}
\hline & ınırsız Yaratıcılığı Teşvik Etme Dav \\
\hline $\begin{array}{l}\text { Yol } \\
\text { Gele } \\
\text { Enfo }\end{array}$ & $\begin{array}{l}\text { Örgütün, çalışanlarına hedefleri, operasyonları ve } \\
\text { görevleriyle meydan okunmasıdır. Insanları, risk } \\
\text { almaya hazırlıklı hale getiren belirsizliğe } \\
\text { toleransın yaygın olmasıdır. Somut deneyimi ve } \\
\text { fırsatları yakalama, detaylı araştırma ve analiz } \\
\text { yapmaya tercih edilir. }\end{array}$ \\
\hline $\begin{array}{l}\text { Değerler: } \\
\text { Enformasyon } \\
\text { Alternatifl } \\
\text { etkiler }\end{array}$ & $\begin{array}{l}\text { Üyeler, biçimsel kurallarla sınırlanmaksızın } \\
\text { örgütün içinde ve dışında, diğerleriyle bir araya } \\
\text { gelmede, karşılıklı ilişki kurmada, inisiyatif } \\
\text { almada kendilerini serbest hissetmeli ve böyle de } \\
\text { çalışmalıdır. Insanlar, birbirlerine güvendikleri } \\
\text { için fikirlerini ve düşüncelerini ileri sürmeye } \\
\text { cesaret etmelidir. }\end{array}$ \\
\hline $\begin{array}{l}\text { Yapılar: Düzenli } \\
\text { Belirgin ve } \\
\text { Rasyonel Bir yar } \\
\text { Olmalıdır. }\end{array}$ & $\begin{array}{l}\text { Yeni fikirler ve değişen inisiyatifler, destekle } \\
\text { karşılanmalıdır. Insanlar, birbirini dinlemeye ve } \\
\text { inisiyatife teşvik etmelidir. Açık ve baskısız bir } \\
\text { atmosferin sürdürülmesi çok tartışılmaktadır. } \\
\text { Tartışmalar, kişisel çatışma ve düşmanlık } \\
\text { tarafından tahrip edilmiş olmamalıdır. }\end{array}$ \\
\hline
\end{tabular}

(Kaynak: Yılmaz, H., (2007). Akademik Yöneticilerin Entelektüel Düzeylerinin Ölçülmesi. Yayınlanmamış Doktora Tezi, Kocaeli Üniversitesi Sosyal Bilimler Enstitüsü, s:185)

Geleceği etkilemek isteyen lider için kurumun yaratıcı potansiyelini geliştirebilmesi hayati önemdedir (Goertz, 2000:158). Dinamik ve özgür bir atmosfer, yaratıcılığın en iyi şekilde gelişebileceği ortamdır. Örgütsel yaratıcılık gelişimi için öncelikle örgüt bireylerinde, yaratıcılığın oluşması gerekir. Bunun içinde çalışanlarda; yüksek kültürel birikim, azim, cesaret, kararlılık, 
hoşgörü, özgür ve bütüncül düşünebilme, geleceğe yönelik vizyonel bakış açısı, tutum ve davranış bütünlüğü gerekli olmaktadır (Yıldırım, 2007:116). Tüm bunları çalışanlarına yani örgüte kazandıracak olan kendisinde bu tür özellikleri bulunduran entelektüel liderdir.

\section{UYGULAMA (APPLICATION)}

\subsection{Amaç (Aim)}

Araştırmanın amacı; Malatya merkezde faaliyet gösteren özel Hizmet işletmeleri yöneticilerindeki entelektüel liderlik düzeyinin, örgütsel yaratıcılık üzerinde ne oranda açıklayıcı etkiye sahip olduğunu ortaya koymaktır.

\subsection{Araştırmanın Varsayımları ve Sınırlılıkları (The Assumption and Limitations)}

Araştırmaya dâhil edilen özel hizmet işletmeleri çalışanlarının, ankette yer alan ifadeleri doğru biçimde anlayıp, tarafsız olarak yorumladıkları ve araştırmanın örnekleminin evreni temsil ettiği varsayılmıştır. Çalışmanın sınırlılıkları ise, araştırmanın sadece bir ilin özel hizmet işletmelerinde yapılmış olması ve araştırmaya katılanların mevcut işyerinde az sayılabilecek bir zamandan beri çalışıyor olmalarıdır. Bu durum çalışanların, gerek yöneticilerini ve gerekse de örgüt faaliyetlerini doğru algılamalarında bir kısıt oluşturmuş olabilir. Bu kısıt, genel olarak araştırmanın tüm bulgularını etkilemiş, değişkenler arası ilişkinin gerçekte olduğundan daha yüksek veya düşük çıkmasına yol açmış olabilir.

\subsection{Araştırmanın Evren ve Örneklemi (Universe and Sample)}

Hizmet sektörünün gelişimi, bir il veya bir ülke için gelişmişliğin göstergesi olabilmektedir. Malatya, Doğu Anadolu Bölgesinde özellikle son ylllardaki gelişimiyle "Büyük Şehir" olmayı hak etmiş bir ildir. Hizmet işletmeleri, yoğun rekabetin ve değişimin yaşandığı bir iş ortamında faaliyetlerini sürdürmektedirler. Bu yüzden hizmet işletmelerinin diğer işletmelerden daha fazla entelektüel lidere ve örgütsel yaratıcılık kabiliyetine ihtiyaçları vardır. Hizmet işletmeleri yöneticileri genelde ileri düzeyde eğitimli kişilerden oluşmaktadır. Bu yüzden hizmet sektöründe, yeterince entelektüel liderlik özelliği olan yöneticilerin olabileceği düşünülmüştür. Bu gerekçelerle araştırmanın çalışma evrenini, Malatya'da faaliyet gösteren özel hizmet işletmelerinde (özel hastane, özel banka, özel eğitim kurs merkezleri) çalışanları oluşturmaktadır. Belirtilen sektörlerin önde gelen yöneticilerinden alınan bilgiler doğrultusunda araştırmanın evreninin yaklaşık 1000 kişiden oluştuğu düşünülmektedir. Araştırmanın örneklemini ise 283 kişi oluşturmaktadır. 1000 kişilik bir evren için o95 güven aralığında ideal örneklem büyüklüğü 278 kişidir (Gürbüz ve Şahin, 2016). Bu bilgi doğrultusunda Değerlendirmeye uygun bulunan anket sayısının sonuçların evrene genelleşebilir olması için yeterli olduğu varsayılmıştır.

\subsection{Araştırmanın Yöntemi (Method)}

Araştırmada veriler, geliştirilen anket aracılığıyla, eğitimli anketörlerle, yüz yüze anket uygulaması ve kolayda örnekleme yöntemi ile toplanmıştır. Bu araştırmada esas olarak nicel araştırma desenlerinden ilişkisel tarama deseni kullanılmıştır. Tarama araştırmasının bir türü olan ilişkisel tarama araştırmalarında genellikle iki veya daha fazla değişken arasında ki ilişkiler ortaya çıkarılmaya çalışılır. "İki veya daha fazla değişken arasındaki birlikte değişimin derecesi nasıldır?" gibi sorular ilişkisel tarama araştırma desenleri ile çözümlenebilir niteliktedir (Gürbüz ve Şahin, 
2016:109). Anket temel olarak 3 bölümden oluşmaktadır. Birinci bölümde araştırmaya katılanların demografik özelliklerine ilişkin sorular yer almaktadır. İkinci bölümde, Ali Akdemir ve Hüseyin Yılmaz'ın çeşitli yayınlarından faydalanılarak ve uzman akademisyenlerin görüşleri alınarak oluşturulan, dokuz soruluk entelektüel liderlik ölçeği yer almaktadır. Üçüncü bölümde ise, Çavuş'un doktora tezinde (2006) kullandığı, 20 soruluk "örgütsel yaratıcılık" ölçeği bulunmaktadır. Ölçekte 5'li likert (1=kesinlikle katılmıyorum; 2=katılmıyorum; 3=kararsızım; 4=katılıyorum; 5=kesinlikle katılıyorum) kullanılmıştır. Toplam 300 anket yüz yüze doldurulmaya çalışılmış ancak 283'ü işleme alınmıştır. Anket yoluyla elde edilen veriler, bilgisayar ortamında tasnif ve analiz edilmiştir. Verilerin çözüm ve yorumlanmasında frekanslar, aritmetik ortalamaların yanı sıra, entelektüel liderlik ile örgütsel yaratıcılık arasındaki ilişkiyi belirlemekte korelasyon, entelektüel liderliğin, örgütsel yaratıcılık üzerindeki açıklayıcı etkisini ortaya koymak için de çoklu regresyon analizinden faydalanılmıştır. Anlamlılık sınırı $\mathrm{p}<0.05$ değeri olarak alınmıştır. Ölçeklerin geçerliliği ve güvenirliliği için keşfedici faktör analizi, Cronbach's Alpha güvenirlilik analizi yapılmıştır. Analizler için SPSS 21.0 programından yararlanılmıştır.

\section{BULGULAR VE YORUMLAR (FINDINGS AND COMMENTS) \\ 5.1. Demografik Değişkenlere İlişkin Bulgular (Demographic Variables Related Findings)}

Araştırmaya dâhil edilen çalışanların demografik özelliklerine yönelik bilgiler Tablo 2 aracılığıyla sunulmuştur.

Tablo 2. Demografik değişkenle ilişkin tanımlayıcı istatistik

(Table 2. Descriptive statistics on demographic variables)

\begin{tabular}{|l|c|c|}
\hline Cinsiyet & Sayı & \% \\
\hline Kadın & 151 & 54,5 \\
\hline Erkek & 126 & 45,5 \\
\hline Toplam & 277 & 100,0 \\
\hline Eğitim & Sayı & $\circ$ \\
\hline lise & 42 & 15,1 \\
\hline Meslek Yüksekokulu & 46 & 16,5 \\
\hline Üniversite & 182 & 65,5 \\
\hline Yüksek Lisans & 8 & 2,9 \\
\hline Toplam & 278 & 100 \\
\hline Işyerinde Geçirilen Süre & Sayı & $\circ$ \\
\hline 5 Yıl ve Altı & 203 & 74,1 \\
\hline $6-10$ Yıl Arası & 58 & 21,2 \\
\hline $11-20$ Yı Arası & 13 & 4,7 \\
\hline Toplam & 274 & 100,0 \\
\hline Yaş & Sayı & $\circ$ \\
\hline 20 ve Altı & 16 & 5,7 \\
\hline $21-30$ Arası & 138 & 48,8 \\
\hline $31-40$ Arası & 112 & 39,6 \\
\hline $41-50$ Arası & 10 & 3,6 \\
\hline Toplam & 276 & 100 \\
\hline Meslekte Geçirilen Süre & Sayı & $\circ$ \\
\hline 5 Yıl ve Altı & 134 & 48,6 \\
\hline $6-10$ Yıl Arası & 87 & 31,5 \\
\hline $11-20$ Yıl Arası & 55 & 19,9 \\
\hline Toplam & 276 & 100 \\
\hline
\end{tabular}

Yukarıdaki Tablo 2'den de anlaşılacağı üzere araştırmaya katılarak ilgili soruya cevap veren, çalışanların "54.5'i" kadın, "45.5'inin" ise erkek; "48.8'inin" 21 ile 30 yaş arasında; 


\begin{abstract}
"\%65.5'inin" üniversite mezunu, "\%48.6'sının" 5 yıl ve altında mesleklerini yaptıkları; "o 74.1'inin" 1-5yıl arası mevcut iş yerinde çalıştığı görülmektedir. Bu tabloya bakıldığında, hizmet işletmelerinde çalışanların yaş ortalamalarının düşük olduğu ve gerek meslek hayatlarında geçen sürenin gerekse de işyerinde geçen sürenin oldukça kısa olduğu söylenebilir.
\end{abstract}

\title{
5.2. Ölçeklerin Geçerliliği, Güvenirliliği ve Ortalamaları (Validity, Reliability and Averages of Scales)
}

Kullanılan ölçeklerin geçerlilik ve güvenilirliklerini test etmek için faktör analizi ve Cronbach's Alpha güvenirlilik analizi yapılmıştır.

\subsubsection{Entelektüel Liderlik Ölçeğine İlişkin Faktör Analizi ve Ortalamalar (Factor Analysis and Means Related to Intellectual Leadership Scale)}

Anketteki soruların kaç değişik boyutta algılandığını ölçmek, değişken sayısını azaltmak ve böylece değişkenler arasındaki ilişkilere dayanarak verilerin daha anlamlı sunulabilmesi için faktör analizi yapılmıştır. Entelektüel liderlik ölçeğine ilişkin faktör analizi sonuçları aşağıda Tablo 3 aracılığı ile sunulmaktadır.

Tablo 3. Entelektüel liderlik ölçeğine ilişkin faktör analizi ve ortalamalar

(Table 3.Factor analysis and means related to intellectual leadership scale)

\begin{tabular}{|c|c|c|c|c|}
\hline \multirow{5}{*}{$\begin{array}{l}\text { Faktör } 1 \\
\text { Bilgisel } \\
\text { Yetenek }\end{array}$} & $\begin{array}{l}\text { Faktör } \\
\text { Yükü }\end{array}$ & Maddeler & \multirow{2}{*}{$\frac{\text { Ort. }}{3.86}$} & \multirow{2}{*}{$\begin{array}{c}\begin{array}{c}\text { Std. } \\
\text { Sapma }\end{array} \\
.941\end{array}$} \\
\hline & .865 & $\begin{array}{l}\text { EL1. Kendi branşına ait bilgisinin yüksek } \\
\text { olduğu gibi yönetim işini de iyi bilir }\end{array}$ & & \\
\hline & .850 & $\begin{array}{l}\text { EL2. Kendisinin ve çalışanların kişisel } \\
\text { gelişimine önem verir }\end{array}$ & 3.74 & .896 \\
\hline & .717 & $\begin{array}{l}\text { EL3. Kurum içinde yapılan faaliyetlere } \\
\text { ilişkin bilginin üretilmesini ve yayılmasını } \\
\text { destekler }\end{array}$ & 3.82 & .959 \\
\hline & .644 & EL4. Yeni fikir ve eylemleri destekler & 3.78 & .941 \\
\hline Açıkladı ğ & varyan & $=\div 32,766$ & alpha & $=0,851$ \\
\hline \multirow{6}{*}{$\begin{array}{l}\text { Faktör } 2 \\
\text { Zihinsel } \\
\text { Yetenek }\end{array}$} & $\begin{array}{l}\text { Faktör } \\
\text { Yükü }\end{array}$ & Maddeler & Ort. & $\begin{array}{l}\text { Std. } \\
\text { Sapma }\end{array}$ \\
\hline & .812 & $\begin{array}{l}\text { EL5. Tüm dünyada olup bitenlere karşı } \\
\text { duyarlıdır }\end{array}$ & 3.66 & .829 \\
\hline & .758 & $\begin{array}{l}\text { EL6. Problemlerin çözümünde entelektüel } \\
\text { kazanımlarını kullanır }\end{array}$ & 3.81 & .901 \\
\hline & .695 & EL7. Muhakeme gücü oldukça fazladır & 3.77 & .880 \\
\hline & .634 & $\begin{array}{l}\text { EL8. İdealleri olan ve bu idealler için } \\
\text { elinden geleni yapan bir insandır }\end{array}$ & 3.96 & .813 \\
\hline & .533 & $\begin{array}{l}\text { EL9. Duygu ve düşüncelerini açık bir şekilde } \\
\text { ifade eder }\end{array}$ & 3.68 & .910 \\
\hline \multicolumn{5}{|c|}{ 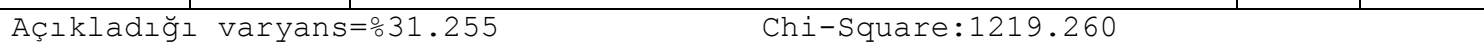 } \\
\hline \multicolumn{5}{|c|}{ Cronbach alpha $=0.813$} \\
\hline \multicolumn{5}{|c|}{ Tüm Ölçek KMO:0.858 } \\
\hline \multicolumn{5}{|c|}{$\begin{array}{l}\text { Faktör analizine ilişkin KMO değerinin "0.858" olması, } \\
\text { değişkenlerin faktör analizine mükemmel derecede uygun olduğunu } \\
\text { göstermektedir (Sipahi 2008). Yapllan faktör analizi sonucuna göre, } \\
\text { entelektüel Liderlik ölçeği iki faktörden oluşmakta ve açıklayabildiği } \\
\text { varyansın "o64.02l" olduğu anlaşllmaktadır. Toplam varyansın açıklana } \\
\text { bilirliğinin "o60"ın" üzerinde olması istatistiksel açıdan tatmin } \\
\text { edici olarak kabul edilmektedir (Nakip, 2006). Ölçeğin güvenilirlik } \\
\text { katsayısı ise "0.885'tir". Faktör analizi ve güvenilirlik analizi } \\
\text { sonucunda } 9 \text { maddeden oluşan ölçeğin güvenilirliğinin ve ölçüm gücünün }\end{array}$} \\
\hline
\end{tabular}


kabul edilebilir sınırların üzerinde olduğu söylene bilinir. Ölçeğin boyutlarından birincisi daha çok liderin bilgiyle ilgili yetenekleriyle ilişkili olduğu için bu faktöre "bilgisel yetenek" adı verilmiştir. İkinci boyut ise liderin daha çok zihinsel yetenekleriyle ilişkili olduğu düşünülerek "zihinsel yetenek" adı verilmiştir.

\subsection{2. Örgütsel Yaratıcılık Ölçeğine İlişkin Faktör Analizi ve Ortalamalar (Factor Analysis and Means Related to Organizational Creativity Scale)}

Örgütsel yaratıcılık ölçeğine ilişkin faktör analizi sonuçları aşağıdaki Tablo 4 aracılığı ile sunulmaktadır.

Tablo 4. Örgütsel yaratıcılık ölçeğine ilişkin faktör analizi ve ortalamalar

(Table 4. Factor analysis and means related to organizational creativity scale)

\begin{tabular}{|c|c|c|c|c|}
\hline \multirow{14}{*}{ 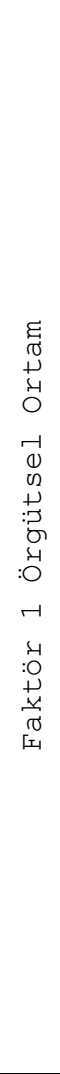 } & $\begin{array}{l}\text { Faktör } \\
\text { Yükü }\end{array}$ & Maddeler & \multirow{2}{*}{ Ort. } & \multirow{2}{*}{$\frac{\text { Std. Sapma }}{1.05218}$} \\
\hline & .793 & $\begin{array}{l}\text { OGY15. isletmemizde yaratıcı sorun çözme } \\
\text { teknikleri sıklıkla kullanılır }\end{array}$ & & \\
\hline & .781 & $\begin{array}{l}\text { OGY16. yaratıcı düşünceyi artıracak bağımsız } \\
\text { çalışma ortamı sunulmaktadır }\end{array}$ & 3.50 & 1.05646 \\
\hline & .772 & $\begin{array}{l}\text { OGY17. isletmemizde yaratıcılık için her } \\
\text { zaman maddi ve manevi destek sağlanır }\end{array}$ & 3.41 & 1.14793 \\
\hline & .764 & $\begin{array}{l}\text { OGY14. başarısızlıklar görmezden gelinip } \\
\text { başarılar ödüllendirilir }\end{array}$ & 3.15 & 1.13168 \\
\hline & .744 & $\begin{array}{l}\text { OGY13. Çalışanların kendi işi dışındaki } \\
\text { isler icinde fikir üretmeleri tevsik edilir. }\end{array}$ & 3.31 & 1.066 \\
\hline & .711 & $\begin{array}{l}\text { OGY19. yaratıcı düşünceler karşılıklı güven } \\
\text { içerisinde ele alınır }\end{array}$ & 3.77 & .98747 \\
\hline & .701 & $\begin{array}{l}\text { OGY12. yaratıcılığı geliştirecek eğitimler } \\
\text { ve gerekli destekler verilir }\end{array}$ & 3.51 & 1.024 \\
\hline & .693 & $\begin{array}{l}\text { OGY6. yaratıcı fikirler için yeterli zaman } \\
\text { sağlanmaktadır }\end{array}$ & 3.47 & 1.029 \\
\hline & .670 & $\begin{array}{l}\text { OGY18. çalışanlardan beklenen yüksek } \\
\text { performans yaratıcılığı artırmaktadır }\end{array}$ & 3.69 & .95625 \\
\hline & .624 & $\begin{array}{l}\text { OGY5. isletmemizde yaratıcılık için uygun } \\
\text { ortam hazırlanmıştır }\end{array}$ & 3.63 & .967 \\
\hline & .621 & $\begin{array}{l}\text { OGY8. Düşüncelerimizi her zaman açıkça ifade } \\
\text { edebiliriz }\end{array}$ & 3.58 & 1.096 \\
\hline & .612 & $\begin{array}{l}\text { OGY10. yaratıcı düşünceler performans } \\
\text { değerlendirilmesinde dikkate alınır }\end{array}$ & 3.61 & 1.054 \\
\hline & .579 & $\begin{array}{l}\text { OGY11.isletmemizde yaratıcılığı engelleyen } \\
\text { örgütsel ve yönetsel faktörler aza } \\
\text { indirgenir }\end{array}$ & 3.54 & 1.002 \\
\hline AÇ I & $\operatorname{ladığı~}$ & $\operatorname{Jaryans}=\frac{0}{0} 40.206$ & lpha $=0$ & 939 \\
\hline $\begin{array}{l}-1 \\
0 \\
0\end{array}$ & $\begin{array}{l}\text { Faktör } \\
\text { Yükü }\end{array}$ & Maddeler & Ort. & Std. Sapma \\
\hline 苟 & .899 & OGY2. isletmemizde öğrenme teşvik edilir & 3.91 & .868 \\
\hline 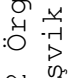 & .804 & $\begin{array}{l}\text { OGY1 İşletmemizin herkesçe paylaşılan } \\
\text { yaratıcı bir vizyonu vardır }\end{array}$ & 3.83 & 1.038 \\
\hline $\begin{array}{ll}1 & 0 \\
: & 0 \\
0 & 0\end{array}$ & .779 & $\begin{array}{l}\text { OGY3. yeni fikirler her zaman değerlemede } \\
\text { dikkate alınır }\end{array}$ & 3.78 & .919 \\
\hline & .647 & $\begin{array}{l}\text { OGY4. yaratıcı olmak için her zaman } \\
\text { cesaretlendiriliriz }\end{array}$ & 3.65 & .976 \\
\hline Aç I & ladığı & $\operatorname{varyans}=\frac{\circ}{2} 22.616 \quad$ Chi-Square: 3405.049 & & \\
\hline Cro & bach al & Tüm ölçeğin açıkladı & I var & $n s=\div 62.822$ \\
\hline Gen & l Ölçek & Tüm ölçek için Cronb & ch alp & $a=0.934$ \\
\hline
\end{tabular}




\subsection{Korelasyon Analizi (Correlation Analysis)}

Özel hizmet işletmelerinde çalışanların, yöneticilerine dönük entelektüel liderlik algılamaları ile örgütsel yaratıcılık algılamaları arasındaki ilişkinin varlığını ve yönünü tespit edebilmek için korelasyon analizi yapılmıştır. Değişkenlere ait ortalama, standart sapma ve korelasyon katsayıları Tablo 5'de gösterilmektedir.

Tablo 5. Değişkenlere ait ortalama, standart sapma ve korelasyon katsayıları $(n=283)$

(Table 5. Mean, Standard deviation and correlation coefficients of variables)

\begin{tabular}{|c|c|c|c|c|c|c|c|c|}
\hline Değişkenler & Ort. & S.S. & 1 & 2 & 3 & 4 & 5 & 6 \\
\hline $\begin{array}{l}\text { 1-Bilgisel } \\
\text { yetenek-Ort }\end{array}$ & 3.8030 & .77661 & 1 & & & & & \\
\hline $\begin{array}{l}\text { 2-Zihinsel } \\
\text { yetenek-Ort }\end{array}$ & 3.7760 & .65622 & $669^{\star *}$ & 1 & & & & \\
\hline $\begin{array}{l}\text { 3-Entelektüel } \\
\text { liderlik-ort }\end{array}$ & 3.7880 & .64834 & $.908^{* \star}$ & $.918^{* \star}$ & 1 & & & \\
\hline $\begin{array}{l}\text { 4-Örgütsel } \\
\text { Ortam-Ort }\end{array}$ & 3.5121 & .79419 & $.540^{\star \star}$ & $.502^{\star \star}$ & $.570^{\star \star}$ & 1 & & \\
\hline $\begin{array}{l}\text { 5-Örgütsel } \\
\text { teşvik Ort }\end{array}$ & 3.7924 & .80141 & $.600^{* *}$ & $.551^{* \star}$ & $.629^{* *}$ & $.676^{\star \star}$ & 1 & \\
\hline $\begin{array}{l}\text { 6-Örgütsel } \\
\text { yaratıcılık- } \\
\text { ort }\end{array}$ & 3.5781 & .74789 & $.590^{\star *}$ & $.547^{\star \star}$ & $.622^{\star *}$ & $.983^{\star \star}$ & $.801^{\star \star}$ & 1 \\
\hline
\end{tabular}

$\star \star \mathrm{p}<.01$

Entelektüel liderlik ve örgütsel yaratıcılık faktörleri arasındaki korelasyon katsayılarına bakıldığında, orta düzeyde pozitif yönlü ilişkilerin olduğu gözlemlenmektedir.

\section{4. Çoklu Regresyon Analizi (Multiple Regression Analysis)}

Yukarıdaki korelasyon analizinden örgütsel yaratıcılığın, entelektüel liderlikle pozitif yönlü orta düzeyde ilişkilerinin olduğu görülmüştür. Ancak, daha sağlıklı bir değerlendirme yapabilmek için entelektüel liderliği oluşturan iki faktör ile örgütsel yaratıcılık arasında çoklu regresyon modeli kurulmuştur. Bir başka ifade ile çoklu regresyon analizi yapılmıştır. Çoklu regresyon analizi bağımlı değişkenle birden fazla bağımsız değişken arasındaki ilişkiler araştırılır. Çoklu regresyon analizinde amaç, bir bağımlı değişken üzerinde birden fazla bağımsız değişkenin etkisini incelemektir (Gürbüz ve Şahin 2016:271). Çoklu regresyon analizi yapılırken örgütsel yaratıcılığın oluşmasında etkisi olabilecek entelektüel liderlik dışındaki tüm etkenlerin sabit oldukları varsayılmıştır. Bununla ilgili sonuçlar ise aşağıda, Tablo 6 ve Tablo 7 ile aktarılmıştır.

Tablo 6. Çoklu regresyon bulguları

(Table 6. Multiple regression findings)

\begin{tabular}{|c|c|c|c|}
\hline \multirow{3}{*}{\multicolumn{2}{|c|}{ Korelasyon Katsayıları }} & Çoklu Korelasyon (r) & .625 \\
\hline & & $\mathrm{R}^{2}$ & .390 \\
\hline & & Düzeltilmiş $\mathrm{R}^{2}$ & .386 \\
\hline \multicolumn{4}{|c|}{ Varyans Analizi Sonuçları } \\
\hline & $\begin{array}{c}\text { Serbestlik } \\
\text { Derecesi }\end{array}$ & Kareler Toplamı & $\begin{array}{c}\text { Kareler } \\
\text { Ortalaması }\end{array}$ \\
\hline Regresyon & 2 & 61.522 & 30.761 \\
\hline Kalıntılar & 280 & 96.210 & .344 \\
\hline \multicolumn{2}{|c|}{$F: 89.524$} & \multicolumn{2}{|c|}{ Anlamlılık:0.000 } \\
\hline
\end{tabular}


Derin, $N$

Social Sciences (NWSASOS), 3C0160, 2017; 12(2): 102-117.

Tablo 7. Çoklu regresyon denklemine ilişkin bulgular

(Table 7 . Findings related to multiple regression equation)

\begin{tabular}{|l|c|c|c|c|c|}
\hline \multicolumn{1}{|c|}{ Açıklama } & \multicolumn{5}{|c|}{ Denklemdeki Değişkenler } \\
\hline Değişkenler & Katsayılar & $\begin{array}{c}\text { Standart } \\
\text { Hatalar }\end{array}$ & $\begin{array}{c}\text { Beta (Standardize } \\
\text { Edilmiş Katsayılar) }\end{array}$ & $t$ & Anlamlılık \\
\hline Sabit & .907 & .210 & & 4.324 & .000 \\
\hline $\begin{array}{l}\text { Bilgisel } \\
\text { Yetenek }\end{array}$ & .391 & .060 & .406 & 6.470 & .000 \\
\hline $\begin{array}{l}\text { Zihinsel } \\
\text { Yetenek }\end{array}$ & .313 & .072 & .275 & 4.382 & .000 \\
\hline $\begin{array}{l}\text { Regresyon } \\
\text { Denklemi }\end{array}$ & $\begin{array}{l}\text { Örgütsel Yaratıcılık= } \\
\text { zihinsel yetenek }\end{array}$ & & & & \\
\hline
\end{tabular}

Çoklu regresyon analizi yapılarak "örgütsel yaratıcılık" bağımlı değişkeni ile entelektüel liderliği oluşturan faktörlerden meydana gelen bağımsız değişkenler arasında ilişki aranmıştır. Çoklu regresyon analizine ilişkin tablolar incelendiğinde, modelin bir bütün olarak geçerli olduğu (F:89.524 ve p:0.000) ve iki bă̆ımsız değişkenin bağımıı değişkendeki değişmelerin "o39'ını" açıklayabildiği görülmektedir. Bağımsız değişkenlerin bağımlı değişken üzerindeki göreli önem sırası, Beta katsayılarına göre değerlendirildiğinde, ilk olarak bilgisel yetenek ikinci olarak zihinsel yetenek olduğu görülmektedir. Regresyon katsayılarının anlamlılığına ilişkin "t testi" sonuçları incelendiğinde ise, liderin bilgisel ve zihinsel yeteneğinin, örgütsel yaratıcılık üzerinde anlamlı birer açıklayıcı oldukları görülmektedir.

\section{SONUÇ VE ÖNERILER (CONCLUSION AND RECOMMENDATIONS)}

Çalışanların yaratıcılık yeteneğini besleyen, yaratıcı iş ortamına olan ilgi her geçen gün artmaktadır. Rekabetçi, çalkantılı bir ekonomik ortamda iş yapan işletmeler için yaratıcılık ve yenilik, diğer öneri ve reçetelerden çok daha önemli olarak düşünülmektedir (Cengiz, vd, 2007:100). Örgütlerin, yeni fikirler üretecek, ürettikleri fikirleri uygulamaya aktaracak, böylelikle bilgi ve teknoloji üretecek, değişime ayak uyduracak, sorunlara farklı çözümler getirecek, yaratıcı bireylere ihtiyacı vardır (Ceylan ve Uğurlu, 2014:96). Bilgi Toplumu; ekonomik sistemlerin, özellikle ağır sanayiden daha fazla olarak hizmetler sektörüne (bilgi sektörü dahil olmak üzere) dayandırıldığı bir sosyal alanı işaret etmektedir. Şu halde Bilgi Toplumu'nda bedensel faaliyet gösteren çalışanlardan daha çoğunlukla entelektüel sermayeleri ile farklılaşan, fark yaratan yeni sınıf çalışanların, işgücü pazarlarına egemen olduğunu söylemek doğru olacaktır.

Bilgi ile donanmış, bağımlılıkları düşük yeni sınıf çalışanların tutundurulması, motive edilmesi, etkinlik, etkililik ve verimliliklerinin arttırılması noktasında elbette yeni sınıf liderlere gereksinim duyulacaktır (Koç, 2006:198-201). Teknik ve mesleki elemanların çoğunlukta olduğu (Sağlık, Eğitim, Finans sektöründeki hizmet işletmelerinde olduğu gibi) bir örgütte yöneticilik işlevini, entelektüel anlamda uzmanlığı en yüksek olan kişi yürütebilir. Bu kişiler modern bir örgütün lideri oldukları için kültürlü insan portresi çizen entelektüel liderlerdir (Yılmaz, 2007:166). Entelektüel liderliğe doğru geçiş, hem yeni örgüt uygulamalarını ve güncel yaklaşımlara odaklanmayı sağlayarak işletme kararlarında isabet derecesini arttıracak hem de keşfedilmemiş çalışan yeteneklerine ulaşmada stratejik bir başarı da getirecektir (Ünal, 2011). Bu araştırmada, Malatya'da faaliyette bulunan özel hizmet işletmeleri yöneticilerinin, entelektüel liderlik düzeylerinin, örgütsel 
Derin, $N$

Social Sciences (NWSASOS), 3C0160, 2017; 12(2): 102-117.

\begin{abstract}
yaratıcılıkla olan ilişkisi ve örgütsel yaratıcılığa olan katkısı araştırılmıştır. Yapılan korelasyon ve çoklu regresyon analizi sonucunda entelektüel liderlikle örgütsel yaratıcılık arasında orta derecede pozitif yönlü ilişkinin varlığı ( $r=622, p \leq 0.01)$ ve entelektüel liderliğin örgütsel yaratıcllık üzerinde "39" gibi önemli sayılabilecek açıklayıcı etkiye sahip olduğu sonucuna ulaşılmıştır. Daha önce yapılan araştırmalarda etik liderlik, transformasyonel liderlik, vizyoner liderlik gibi liderlik tarzlarının, liderin duygusal zekasının, üyeleriyle olan etkileşiminin örgütsel yaratıcılığı etkilediği sonuçlarına ulaşılmıştır. Bu araştırmayla da örgütsel yaratıcılık üzerinde beklide en önemli etkiyi oluşturacağı düşünülen entelektüel liderliğin, örgütsel yaratıcılık üzerindeki açıklayıcı etkisi ortaya konmuştur. Bu sonuca bağlı olarak, örgütlerinin yaratıcılık düzeylerini, yenilik yapma potansiyelini artırmak isteyen lider yöneticilerin, öncellikle kendi entelektüel düzeylerini artırmaları gerekeceği söylenebilir. Entelektüellik kapasitesini her geçen gün artıran lider yönetici, örgütün yaratıcılık yönünde kapasitesinin artması için uygun ortamı da oluşturabilir. Böylelikle, örgütte yeni fikirler, yeni süreçler, yeni ürünler geliştirilir. Örgütün yenilik yapma becerisinin artmasıyla, değişen ekonomik çevreye ayak uydurması, rekabet avantajı elde etmesi, her türlü çıkar grubunun kazancını maksimize etmesi mümkün hale gelir. Bu araştırmanın en önemli kısıdı, sadece bir ilin özel hizmet işletmelerinde gerçekleştirilmesi ve araştırmaya katılanların büyük bir çoğunluğunun mevcut işyerinde çok az zamandır (\%74.1'inin, 5 yıl ve altında) çalışıyor olmalarıdır. Özel işletmelerin en önemli problemlerinden birisi işgücü devir oranlarının yüksek olmasıdır. Bu genel durum araştırmaya da yansıdığı düşünülmektedir. Bu durum, araştırmaya katılanların gerek yöneticilerini ve gerekse de örgüt faaliyetlerini doğru algılamalarında bir kısıt oluşturmuş olabilir. Konuyla ilgilenen araştırmacılar, işgücü devrinin çok yüksek olmayacağı kamu sektöründe veya büyük işletmelerde benzer çalışmalar yapabilirler. Özellikle entelektüel liderliğin, yazında çok işlenmemiş fakat örgütsel davranış açısından oldukça önemli bir konu olduğu düşünülmektedir. Araştırmacılar entelektüel liderliğin olumlu veya olumsuz diğer örgütsel davranışları (örgütsel bağlılık, örgütsel özdeşleşme, örgütsel vatandaşlık, örgüte güven, işten ayrılma niyeti, örgütsel sessizlik veya seslilik vb.) nasıl şekillendirdiğine yönelik araştırmalar yapabilirler.
\end{abstract}

\title{
KAYNAKLAR (REFERENCES)
}

1. Akdemir, A., (2002). Entelektüel Liderlik, http://www.hurriyet.com.tr/entelektuel-liderlik-104785, (Erişim:26.09.2016).

2. Akdemir, A., (2008). Vizyon Yönetimi, Birey, Kurum, Kent ve Ülke Düzeyinde. Ekin Basın Yayın Dağıtım, Bursa.

3. Akdemir, A., (2004). Entelektüel Liderlik, http: //www.tuncaycalhan.org/mak/16.pdf, (Erişim:29.09.2016).

4. Ayyıldız Ünnü, N.A., (2014). Değişime Liderlik Etmek. Burak Çapraz (Ed.), Değişim Kitabı, İçinde (s:31-68).

5. Budak, G. ve Budak, G., (2004). İşletme Yönetimi: Barış Yayınları, İzmir.

6. Cengiz, E., Acuner, T. ve Baki, B., (2007). Örgütsel Yaratıcılığı Belirleyen Faktörler Arası Yapısal İlişkiler, Dokuz Eylül Üniversitesi Sosyal Bilimler Enstitüsü Dergisi, 9(1), 98-120. 
Derin, $N$.

Social Sciences (NWSASOS), 3C0160, 2017; 12(2): 102-117.

7. Cheung, M.F.Y. and Wong, C.S., (2011). Transformational

Leadership, Leader Support, and Employee Creativity, Leadership

\& Organization Development Journal, 32(7), 656-672.

8. Çavuş, M.F., (2006). İşletmelerde Personel Güçlendirme Uygulamalarının Örgütsel Yaratıcılık ve Yenilikçiliğe Etkileri Üzerine Imalat Sanayinde Bir Uygulama, Yayınlanmamış Doktora Tezi, Konya: Selçuk Üniversitesi Sosyal Bilimler Enstitüsü, Konya

9. Çă̆an, K., (2005a). Entelektüel İmgesi Üzerine. Kenan Çă̆an. (Ed.), Entelektüel Lider ve İktidar, İçinde (s:9-22). Hece Yayınları, Ankara.

10. Çă̆an, K., (2005b). İktidarla İmtihan Süreçlerinde Entelektüelin Durumu. Kenan Çă̆an. (Ed.), Entelektüel Lider ve İktidar İçinde (s:155-176). Hece Yayınları, Ankara.

11. Chughtai, A.A., (2016). Can Ethical Leaders Enhance Their Followers' Creativity?, Leadership, 2(2), 230-249.

12. Dealtry, R., (2001). Managing Intellectual Leadership in Corporate Value, Journal of Workplace Learning, 13(3), 119-124.

13. Demir Uslu, Y., (2011). Örgütlerde Yönetsel Etkinliğe Ulaşmada Yeni Bir Yaklaşım: Yaratıcı Liderlik, Selçuk Üniversitesi Sosyal ve Ekonomik Araştırmalar Dergisi, 22, 419-443.

14. Dess, G.G. and Pickens, J., (2000). Changing Roles: Leadership in The 21 Century, Organizational Dynamics, 78, 18-34.

15. Dewett, T. ve Gruys, M.L., (2007). Advancing The Case for Creativity through Graduate Business Education, Thinking Skills and Creativity, 2, 85-95.

16. Erdoğdu, M.Y., (2006). Yaratıcılık İle Öğretmen Davranışları ve Akademik Başarı Arasındaki İlişkiler, Elektronik Sosyal Bilimler Dergisi, www.e-sosder.com, 5(17), 95-106.

17. Goertz, J., (2000). Creativity: An Essential Component For Effective Leadership in Today's Schools, Roeper Review, 22 (3), 158-162.

18. Gümüşlüoğlu, L. and Ilsev, A., (2009). Transformational Leadership, Creativity and Organizational Innovation, Journal of Business Research, 62, 461-473.

19. Gürbüz, S. ve Şahin, F., (2016). Sosyal Bilimlerde Araştırma Yöntemleri, Seçkin Yayıncılık, Ankara.

20. Iraz, R ve Akyazı, T.E., (2015). Örgütsel Yaratıcılık Modelinin Oluşmasında Bireysel Yaratıcılık ve Örgüt İkliminin Etkisi: Aksaray İlinde Bir Araştırma, 2. Yükseköğretim Stratejileri ve Kurumsal İşbirliği Sempozyumu, Silifke-Mersin.

21. Kazanjian, R.K., Drazin, R., and Glynn, M.A., (2000). Creativity and Technological Learning: The Roles of Organization Architecture and Crisis in Large-Scale Project, J. Eng. Technol. Manage. 17, 273-298.

22. Koç, O., (2006). Bilgi Toplumu Organizasyonlarında Örgüt İçi Çatışmaların Yönetiminde Entelektüel Liderliğin Rolü, Yayınlanmamış Doktora Tei, Kocaeli Üniversitesi Sosyal Bilimler Enstitüsü, Kocaeli.

23. Kratzer, J., Leenders, R., Jo, M.L., and Engelen, V., (2008). The Social Structure of Leadership and Creativity in Engineering Design Teams: An Empirical Analysis, J. Eng. Technol. Manage. $25,269-286$.

24. Macfarlane, B. and Chan, R.Y., (2014). The last judgement: Exploring Intellectual Leadership in Higher Education Through Academic Obituaries, Studies in Higher Education, 39(2), $294-$ 306 . 
Derin, $N$.

25. Mainemelis, C. and Ronson, S., (2006). Ideas Are Born in Fields of Play: Towards Theory of Play and Creativity in Organizational Settings, Research in Organizational Behavior, 27, 81-131.

26. Matthews, D., (2008). Special Event Production The Process, Chapter 5, The Production Team, 79-95.

27. Macfarlane, B., (2011). Professors as Intellectual Leaders: Formation, Identity and Role, Studies in Higher Education, $36(1), 57-73$.

28. Mısırdalı Yangil, F., (2026), Bilgi Toplumunda Liderlik: Sürdürülebilir Liderlik, Dumlupınar Üniversitesi Sosyal Bilimler Dergisi, 48, 128-143.

29. Nakip, M., (2006). Pazarlama Araştırmaları, Teknikler ve (SPSS destekli9 Uygulamalar, Seçkin Yayıncılık, Ankara.

30. Qu, R., Janssen, O., and Shi, K., (2015). Transformational Leadership and Follower Creativity: The Mediating Role of Follower Relational Identi fication and The Moderating Role of Leader Creativity Expectation, The Ledership Quarterly, 26(2), 286-299.

31. Özsevgeçi, T. ve Aytar, A., (2014).Öğretmen Adaylarının Kamusal Entelektüellik Düzeylerinin Belirlenmesi: Bir Ölçek Geliştirme Çalışması ve Ölçeğin Uygulanması, Ondokuz Mayıs Üniversitesi Eğitim Fakültesi Dergisi, 33(2), 642-663.

32. Rice, G., (2006), Individual values, Organizational Context, and Self-Perceptions of Employee Creativity: Evidence from Egyptian Organizations, Journal of Business Research, 59, 233-241.

33. Phillips, J., (2007), Orijinal Düşünme Sanatı, Çeviri: Jule Gülmen, Global Yayın Dağıtım, İstanbul.

34. Sehat, A., (2010), The Relationship Between Principals' Creativity and Personnel's Productivity in Technical-Vocational Colleges, Procedia Social and Behavioral Sciences, 5, 2277-2281.

35. Sipahi, B., Yurtkoru, S. ve Çinko, M., (2008), Sosyal Bilimlerde Spss'le Veri Analizi: Beta Basım Yayım Dağıtım A.Ş., İstanbul

36. Söylemezoğlu, E., (2011). Entelektüel Liderlik, Http://Ergulsoylemezoglu.Blogspot.Com.Tr/P/Yeni-Bloglar.Html, Erişim: Eylül 2016.

37. Tabak, A. ve Sığrı, Ü., (2014). Liderlik (Ed:) Sığrı A. ve Gürbüz, S., Örgütsel Davranış, İçinde (s:371-429) Beta Yayıncılık, İstanbul.

38. Tabassi, A.A., Roufechaei, K.M., Ramli, M., Abu Bakar, A.H., Radzi, I.A., and Pakir, H.K., (2016). Leadership competences of Sustainable Construction Project Managers, Journal of Cleaner Production, 124, 339-349.

39. Tekin, M. ve Akkolaş, D.A., (2005). Hizmet İşletmelerinde Bilişim Teknolojisinin Stratejik Kullanımına İlişkin Bir Hastane Uygulaması, V. Ulusal Üretim Araştırmaları Sempozyumu, İstanbul Ticaret Üniversitesi, 25-27, 521-526.

40. Tierney, P., Farmer, S., and Graen, G., (1999). An Examination of Leadership and Employee Creativity: The Relevance of Traits and Relationships, Personnel Psychology, 52, 591-620.

41. Uğurlu, C.T. ve Ceylan, N., (2014). Öğretmenlerin Örgütsel Yaratıcılık ve Etik Liderlik Algılarının İncelenmesi, Mersin Üniversitesi Eğitim Fakültesi Dergisi, 10(2), 96-112.

42. Uslu, B. ve Arslan, H., (2015). Öğretim Üyelerinin Akademik Entelektüel Liderliği: Üniversitelerin Bazı Örgütsel Özellikleri ile Yordayıcı İlişkileri, Yükseköğretim ve Bilim Dergisi, 5(2), $125-135$. 
43. Uslu, B., (2016). Faculty's Academic Intellectual Leadership within the Conditions of Modern Universities, Education and Science, 41 (184), 193-211.

44. Uysal, O., ( 2007). Liderliğin Anatomisi, Akçağ Yayınları, Ankara.

45. Ünal, H., (2011). Entelektüel Liderlik ve Önemi Nedir?, http: //www.webmastersitesi.com/ekonomi/247351-entelektuelliderlik-ve-onemi-nedir.htm, Erişim: 28.09.2016.

46. Yıldırım, E., (2000). Bilgi Çă̆ında Yaratıcılığın ve Yaratıcılığı Yönetmenin Önemi, Selçuk Üniversitesi Karaman İ.̇.B.F Dergisi, 12, 109-120.

47. Yılmaz, H., (2007). Akademik Yöneticilerin Entelektüel Düzeylerinin Ölçülmesi, Yayınlanmamış Doktora Tez, Kocaeli Üniversitesi Sosyal Bilimler Enstitüsü, Kocaeli.

48. Yılmaz, H. ve Karahan, A., (2010). Liderlik Davranışı, Örgütsel Yaratıcılık ve İşgören Performansı Arasındaki İlişkilerin İncelenmesi: Uşak'ta Bir Araştırma, Yönetim Ve Ekonomi, 17(2), 145-158.

49. Yılmaz, H., (2014). Bilgi Liderliğinin İşletme Performansı Üzerine Etkilerinin Değerlendirilmesi, Optimum Ekonomi ve Yönetim Bilimleri Dergisi, 1(1), 51-68.

50. Yılmaz, H., (2004). Bilgi Çă̆ı Sonrası Liderlik Modeli Olarak Entelektüel Liderlik, http://www.koniks.com/topic.asp?TOPIC_ID=762, (Erişim: 28 Eylül 2016).

51. Yılmaz, E., (2010). The Analysis of Organizational Creativity in Schools Regarding Principals' Ethical Leadership Characteristics, Procedia Social and Behavioral Sciences, 2, 3949-3953.

52. Yurtseven, R., (2001). Yaratıcı Yönetim, Çanakkale Onsekiz Mart Üniversitesi Yayını, 1.Baskı, Çanakkale. 